\title{
Catalyst-Transfer Polycondensation for the Synthesis of Poly(p-phenylene) with Controlled Molecular Weight and
}

\author{
Low Polydispersity
}

Ryo Miyakoshi, Kyohei Shimono, Akihiro Yokoyama, and Tsutomu Yokozawa*

\section{Supporting Information}

\section{Experimental.}

General. ${ }^{1} \mathrm{H}$ and ${ }^{13} \mathrm{C}$ NMR spectra were obtained on a JEOL ECA-600 using tetramethylsilane (TMS) as an internal standard. The $M_{\mathrm{n}}$ and $M_{\mathrm{w}} / M_{\mathrm{n}}$ of polymers were measured with a TOSOH HLC-8020 gel-permeation chromatography (GPC) unit (eluent: THF; calibration: polystyrene standards) using two TSK-gel columns $(2 \times$ Multipore $\left.\mathrm{H}_{\mathrm{XL}}-\mathrm{M}\right)$. Conversion of monomer was determined by analytical $\mathrm{GC}$ performed on a Shimadzu GC-14B gas chromatograph equipped with a GL Science dimethylsilicone fluid OV-101 column $(3 \mathrm{~m})$ and a FID detector, and analyses of conversion were carried out with naphthalene as an internal standard. 1,4-Dibromo-2,5-dimethylbenzene (TCI), 1-bromohexane (Aldrich), hydroquinone (Wako), lithium chloride (Wako), isopropylmagnesium chloride (2.0 M solution in THF, Aldrich), [1,3-bis(diphenylphosphino)propane]dichloronickel(II) (Ni(dppp) $\left.\mathrm{Cl}_{2}, \mathrm{TCI}\right)$, [1,2-bis(diphenylphosphino)ethane]dichloronickel(II) $\quad\left(\mathrm{Ni}(\mathrm{dppe}) \mathrm{Cl}_{2}, \quad\right.$ Aldrich), [1,1'-bis(diphenylphosphino)ferrocene]dichloronickel(II) ( $\mathrm{Ni}(\mathrm{dppf}) \mathrm{Cl}_{2}$, Aldrich), dry acetone (Wako), and dry tetrahydrofuran (THF, stabilizer free, Kanto) were used as received without purification. Naphthalene, which was used as an internal standard for $\mathrm{GC}$ analysis, was purified by recrystallization from $\mathrm{MeOH}$. 
Synthesis of 1,4-dibromo-2,5-dihexyloxybenzene (2). This compound was synthesized by the procedure as shown in Scheme S1.

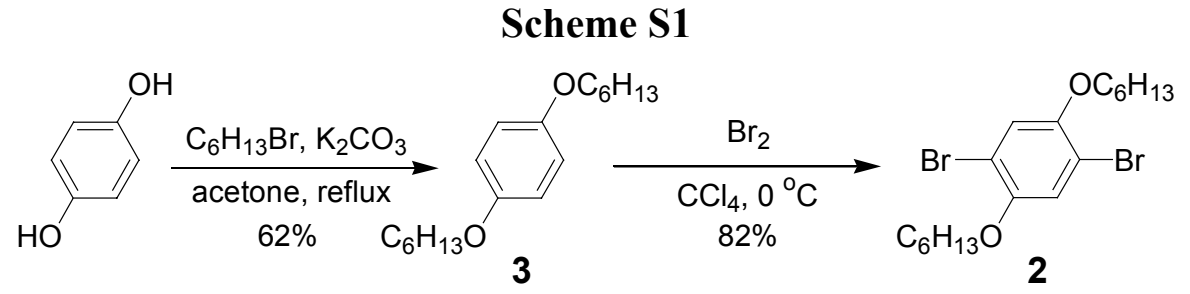

p-Dihexyloxybenzene (3). ${ }^{1} \quad$ 1-Bromohexane $(15.5 \mathrm{~mL}, 110 \mathrm{mmol})$ was added to a mixture of hydroquinone $(5.506 \mathrm{~g}, 50.00 \mathrm{mmol})$ and $\mathrm{K}_{2} \mathrm{CO}_{3}(24.98 \mathrm{~g}, 181 \mathrm{mmol})$ in dry acetone $(121 \mathrm{~mL})$, and the reaction mixture was stirred at reflux for $3 \mathrm{~d}$. After addition of water, the mixture was extracted with $\mathrm{Et}_{2} \mathrm{O}$. The organic layer was washed with $10 \%$ aqueous $\mathrm{Na}_{2} \mathrm{~S}_{2} \mathrm{O}_{3}$ and water, and dried over anhydrous $\mathrm{MgSO}_{4}$. After filtration and evaporation, the residue was purified by silica gel column chromatography $($ AcOEt $/$ hexane $=1 / 25)$ to give 3 as a white solid $(8.676 \mathrm{~g}, 62 \%) . \mathrm{mp} 42.6-42.8^{\circ} \mathrm{C}$ (lit. ${ }^{1}{ }^{1}$ mp 44-45 $\left.{ }^{\circ} \mathrm{C}\right) ;{ }^{1} \mathrm{H}$ NMR (600 MHz, $\left.\mathrm{CDCl}_{3}\right) \delta 6.82$ (s, $\left.4 \mathrm{H}\right), 3.90(\mathrm{t}, J=6.5 \mathrm{~Hz}, 4 \mathrm{H}$ ), 1.75 (quint, $J=7.1 \mathrm{~Hz}, 4 \mathrm{H}), 1.47-1.42(\mathrm{~m}, 4 \mathrm{H}), 1.35-1.31(\mathrm{~m}, 8 \mathrm{H}), 0.90(\mathrm{t}, J=7.0$ $\mathrm{Hz}, 6 \mathrm{H}) ;{ }^{13} \mathrm{C} \mathrm{NMR}\left(150 \mathrm{MHz}, \mathrm{CDCl}_{3}\right) \delta 153.2,115.4,68.7,31.6,29.4,25.7,22.6$, 14.0.

1,4-Dibromo-2,5-dihexyloxybenzene (2). ${ }^{2}$ Bromine $(1.6 \mathrm{~mL}, 31 \mathrm{mmol})$ was added to a solution of $3(3.478 \mathrm{~g}, 12.49 \mathrm{mmol})$ in $\mathrm{CCl}_{4}(15.5 \mathrm{ml})$ at $0{ }^{\circ} \mathrm{C}$, and the reaction mixture was stirred at room temperature for $2 \mathrm{~h}$. After addition of $20 \%$ aqueous $\mathrm{KOH}$, the mixture was extracted with $\mathrm{CH}_{2} \mathrm{Cl}_{2}$. The organic layer was washed with water, and dried over anhydrous $\mathrm{MgSO}_{4}$. After filtration and evaporation, the residue was purified by recrystallization from $\mathrm{CH}_{2} \mathrm{Cl}_{2}-\mathrm{EtOH}$ to give 2 as a white solid (4.440 g, 82\%). mp 61.9-62.1 ${ }^{\circ} \mathrm{C} ;{ }^{1} \mathrm{H}$ NMR (600 MHz, $\left.\mathrm{CDCl}_{3}\right) \delta 7.09$ (s, $\left.2 \mathrm{H}\right), 3.95(\mathrm{t}, J=6.5 \mathrm{~Hz}, 4 \mathrm{H})$, 1.80 (quint, $J=7.0 \mathrm{~Hz}, 4 \mathrm{H}), 1.51-1.46(\mathrm{~m}, 4 \mathrm{H}), 1.37-1.32(\mathrm{~m}, 8 \mathrm{H}), 0.90(\mathrm{t}, J=7.0$ $\mathrm{Hz} 6 \mathrm{H}) ;{ }^{13} \mathrm{C}$ NMR $\left(150 \mathrm{MHz}, \mathrm{CDCl}_{3}\right) \delta 150.1,118.5,111.1,70.3,31.5,29.1,25.6,22.6$, 14.0.

General procedure of polymerization. All glass apparatuses were dried prior to use. Addition of reagents into a reaction flask and withdrawing a small aliquot of the reaction mixture for analysis were carried out via a syringe from a three-way stopcock with a stream of nitrogen. A round-bottomed flask equipped with a three-way stopcock containing lithium chloride $(42.4 \mathrm{mg}, 1.00 \mathrm{mmol}$ ) was heated under reduced pressure, and then cooled to room temperature under a nitrogen atmosphere. Monomer $2(0.436 \mathrm{~g}$, $1.00 \mathrm{mmol}$ ) and naphthalene (used as an internal standard for GC analysis, $64.2 \mathrm{mg}$, $0.501 \mathrm{mmol}$ ) were placed in the flask, and the atmosphere in the flask was replaced with nitrogen. Into the flask was added THF $(5.0 \mathrm{~mL})$ via a syringe, and the mixture was stirred at room temperature. Isopropylmagnesium chloride $(2.0 \mathrm{M}$ solution in THF, 0.50 
$\mathrm{mL}, 1.0 \mathrm{mmol}$ ) was added via a syringe, and the mixture was stirred at room temperature for $1 \mathrm{~d}$ (conversion of $\mathbf{2}$ to 1 was $82 \%$ by analytical GC). To the mixture was added a suspension of $\mathrm{Ni}(\mathrm{dppe}) \mathrm{Cl}_{2}(7.4 \mathrm{mg}, 0.014 \mathrm{mmol}, 1.4 \mathrm{~mol} \%)$ in THF (5.0 $\mathrm{mL}$ ) via a syringe, and then the mixture was stirred at room temperature. After the reaction mixture was stirred for $15 \mathrm{~h}$ (conversion of $\mathbf{1}=91 \%$ ), $5 \mathrm{M}$ hydrochloric acid was added and the mixture was extracted with $\mathrm{CHCl}_{3}$. The organic layer was washed with water, dried over anhydrous $\mathrm{MgSO}_{4}$, and concentrated under reduced pressure. To the residue was added $\mathrm{MeOH}$. The insoluble material was washed well with $\mathrm{MeOH}$ and collected by suction filtration to give pure poly ( $p$-phenylene) $\left(M_{\mathrm{n}}=19600, M_{\mathrm{w}} / M_{\mathrm{n}}=\right.$ 1.14) as a white solid (179 mg, 79\%). $\left.{ }^{1} \mathrm{H} \mathrm{NMR} \mathrm{(600} \mathrm{MHz,} \mathrm{CDCl}_{3}\right) \delta 7.10(\mathrm{~s}, 2 \mathrm{H})$, $3.92(\mathrm{t}, 4 \mathrm{H}), 1.70-1.67$ (m, $4 \mathrm{H}), 1.38-1.26(\mathrm{~m}, 12 \mathrm{H}), 0.87$ (t, $6 \mathrm{H})$.

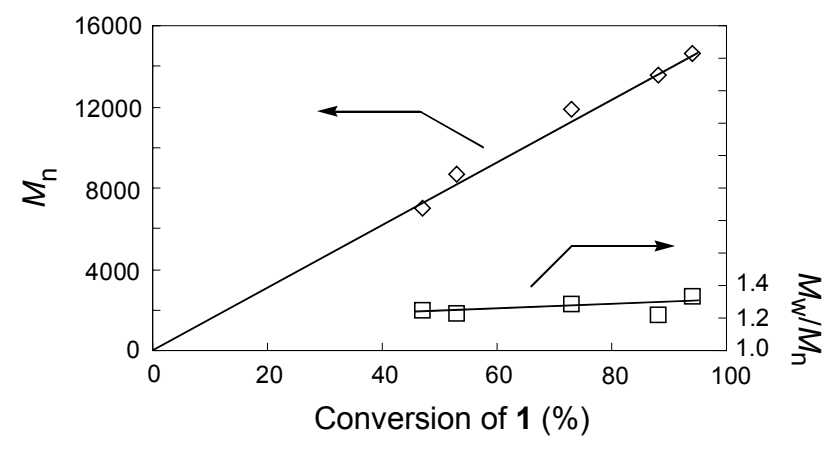

Figure S1. $\quad M_{\mathrm{n}}$ and $M_{\mathrm{w}} / M_{\mathrm{n}}$ values of PPP as a function of monomer conversion in the polymerization of $\mathbf{1}$ with $1.8 \mathrm{~mol} \%$ of $\mathrm{Ni}(\mathrm{dppp}) \mathrm{Cl}_{2}$ in $\mathrm{THF}$ at room temperature $\left([\mathbf{1}]_{0}=0.08 \mathrm{M}\right)$.

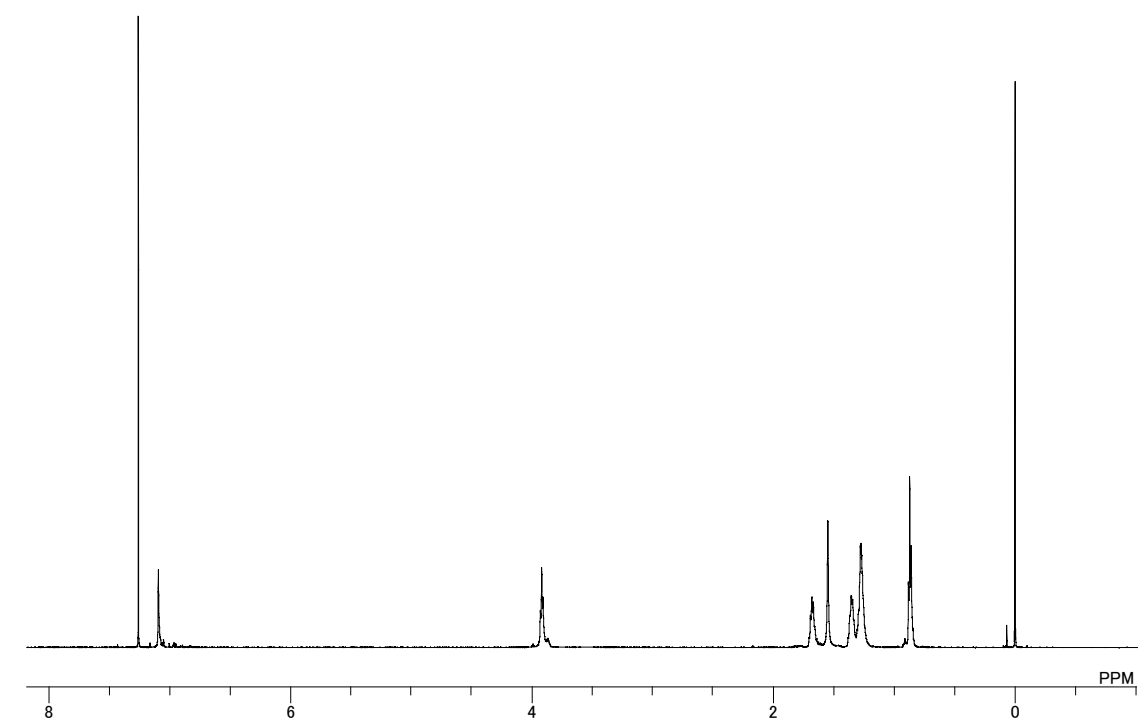

Figure S2. $\quad{ }^{1} \mathrm{H}$ NMR spectrum of PPP in $\mathrm{CDCl}_{3}$. 


\section{References}

(1) Plater, M. J.; Sinclair, J. P.; Aiken, S.; Gelbrich, T.; Hursthouse, M. B. Tetrahedron 2004, 60, 6385-6394.

(2) Maruyama, S.; Kawanishi, Y. J. Mater. Chem. 2002, 12, 2245-2249. 